\title{
Pengaruh Konsumsi Fast Food, Asupan Sarapan Pagi dan Aktivitas Fisik terhadap Kejadian Obesitas pada Remaja Putri
}

\author{
Rilla Simpati ${ }^{1}$, Retno Sugesti ${ }^{2}$ \\ ${ }^{1,2}$ Program Studi Kebidanan Program Sarjana Terapan \\ Sekolah Tinggi Ilmu Kesehatan Indonesia Maju \\ Jln. Harapan No. 50, Lenteng Agung, Jakarta Selatan - Indonesia \\ Email: 1rillasimpati98@gmail.com 2retnosugesti.stikim@@gmail.com
}

Editor: H, Nina

Hak Cipta:

(C)2021 Artikel ini memiliki akses terbuka dan dapat didistribusikan berdasarkan ketentuan Lisensi Atribusi Creative Commons, yang memungkinkan penggunaan, distribusi, dan reproduksi yang tidak dibatasi dalam media apa pun, asalkan nama penulis dan sumber asli disertakan. Karya ini dilisensikan di bawah Lisensi Creative Commons Attribution Share Alike 4.0 Internasional.

\section{A B S T R A C T}

Introduction: Obesity has become a worldwide epidemic health problem. The World Health Organization (WHO) states that more than 1.9 billion adults aged 18 years and over are overweight and 600 million of them are obese. In 2014 an estimated 41 million children under the age of 5 are obese.

Objectives: aiming to determine the effect of the influence of fast food consumption, breakfast intake and physical activity on the incidence of obesity in adolescent girls at the Bekasi 13th high school in 2019.

Method: This study uses the Stuctural Equation Modeling (SEM) method with the Crossapproach Sectional. The total population in this study was 118 respondents, the determination of the number of samples that were reseventative with a total sample of 70 respondents taken using accidental sampling technique. The research instrument was tested for validity and reliability testing, the instrument used in this study was a questionnaire.

Result: The results in this study there is a direct effect of fast food consumption on the incidence of obesity $(9.45 \%$, T Statistic $4.06 \%, \alpha$ $5 \%$ ), there is a direct effect on breakfast intake on the incidence of obesity (4.04\%, T Statistic 3, 04\%, $\alpha$ 5\%), there is a direct influence of physical activity on the incidence of obesity $(5.00 \%$, Statistical T value $2.67 \%$ \% $5 \%$ ).

Conclution: The conclusion is there is the influence of fast food consumption, breakfast intake and physical activity on the incidence of obesity in adolescent girls in Bekasi 13th High School in 2019. The suggestion is expected that adolescents reduce consuming fast food so that health is maintained and prevent obesity.

Keyword: Fast Food Consumption, Obesity. 


\section{SIMFISIS Jurnal Kebidanan Indonesia}

Volume 01, Nomor 01, Agustus 2021

\section{Pendahuluan}

Obesitas adalah kelebihan kandungan lemak di jaringan adiposa. Batas umum untuk obesitas umumnya adalah kelebihan berat lebih dari $20 \%$ standar normal. ${ }^{1}$ Remaja merupakan aset bangsa untuk terciptanya generasi yang baik di masa mendatang. Masa remaja atau adolescent adalah waktu terjadinya perubahan-perubahan yang berlangsungnya cepat dalam hal pertumbuhan fisik, kognitif, dan psikososial atau tingkah laku. ${ }^{2}$ Masa remaja merupakan salah satu periode tumbuh kembang yang penting dan menentukan pada periode perkembangan berikutnya. Remaja yang mengalami obesitas, kelak pada masa dewasa cenderung obesitas. Hal ini telah dibuktikan bahwa insiden obesitas pada periode transisi antara remaja dan dewasa muda dalam kurun waktu lima tahun meningkat, yaitu dari 10,9\% menjadi $22,1 \%$ dan $4,3 \%$ di antaranya mempunyai IMT $40 .^{3}$

Obesitas pada remaja penting untuk diperhatikan karena remaja yang mengalami obesitas $80 \%$ berpeluang untuk mengalami obesitas pula pada saat dewasa. Selain itu, terjadi peningkatan remaja obesitas yang didiagnosis dengan kondisi penyakit yang biasa dialami orang dewasa, seperti diabetes tipe 2 dan hipertensi. Remaja obesitas sepanjang hidupnya juga berisiko lebih tinggi untuk menderita sejumlah masalah kesehatan yang serius, seperti penyakit jantung, stroke, diabetes, asma, dan beberapa jenis kanker. Stigma obesitas juga membawa konsekuensi psikologis dan sosial pada remaja, termasuk peningkatan risiko depresi karena lebih sering ditolak oleh rekan-rekan mereka serta digoda dan dikucilkan karena berat badan mereka. ${ }^{4}$ Obesitas telah menjadi masalah kesehatan yang epidemi di seluruh dunia. World Health Organization (WHO) mengatakan bahwa lebih dari 1,9 miliar orang dewasa berusia 18 tahun ke atas mengalami berat badan berlebih dan 600 juta orang diantaranya mengalami obesitas. Pada tahun 2014 diperkirakan 41 juta anak di bawah usia 5 tahun mengalami obesitas. $^{5}$

Menurut hasil riset kesehatan dasar tahun 2018, tingkat obesitas pada orang dewasa di Indonesia meningkat menjadi 21,8 persen. Prevalensi ini meningkat dari hasil Riskesdas 2013 yang menyebut bahwa angka obesitas di Indonesia hanya mencapai 14,8 persen. Obesitas sendiri mengacu pada kondisi di mana indeks massa tubuh diatas 27 . Begitu juga dengan prevalensi berat badan berlebih dengan indeks massa tubuh antara 25 hingga 27, juga meningkat dari 11,5 persen di 2013 ke 13,6 persen di $2018 .{ }^{6}$

Gambaran umum permasalahan obesitas di Jawa Barat tahun 2016, dengan melakukan pengukuran obesitas, diperiksa sebanyak 1.644 .079 orang dan terindikasi obesitas sebanyak 138.965 orang $(8,45 \%)$ pelaporan berasal dari 23 Kabupaten/Kota $(85,18 \%)$, dengan angka obesitas terbesar di Kota Cimahi $100 \%$ dan terendah Kab.Ciamis 0,01 \%. Kabupaten/kota yang tidak melaporkan kegiatan pemeriksaan obesitas adalah Kab.Cianjur, Kab.Tasikmalaya, Kab Bandung Barat, dan Kota Bandung. ${ }^{7}$ Faktor-faktor yang dapat mempengaruhi kejadian obesitas pada remaja adalah asupan protein, asupan lemak, asupan karbohidrat, asupan serat, pola konsumsi fast food, asupan sarapan pagi, aktivitas fisik, faktor psikologis (harga diri) dan faktor genetik (status obesitas orang tua). ${ }^{8}$

Fast food atau makanan siap saji. Makanan siap saji yang dimaksud adalah jenis makanan yang dikemas, mudah disajikan, praktis, atau diolah dengan cara sederhana. Makanan tersebut umumya diproduksi oleh industri pengolahan pangan dengan teknologi tinggi dan memberikan berbagai zat aditif untuk mengawetkan dan memberikan cita rasa bagi produk tersebut. Makanan siap saji biasanya berupa lauk pauk dalam kemasan, mie instan, nugget, atau juga corn flakes sebagai makanan untuk sarapan. ${ }^{9}$ Dari penelitian yang telah dilakukan oleh Sarbia A.Takumansang pada tahun 2017, hasil analisis uji Kendall Tau menunjukkan adanya hubungan konsumsi fast food terhadap obesitas remaja di SMP Muhammadiyah 9 Yogyakarta ditunjukkan dengan nilai 0,564 dengan $\mathrm{p}=0,01(\mathrm{p}<0,05) .{ }^{10}$

Sarapan sebaiknya mengandung makanan sumber karbohidrat, protein, tinggi serat, dan rendah 


\section{SIMFISIS Jurnal Kebidanan Indonesia}

Volume 01, Nomor 01, Agustus 2021

lemak. Melewatkan sarapan dapat berisiko untuk menjadi obesitas dan memiliki gangguan kesehatan. Obesitas dapat terjadi karena ketika anak tersebut melewatkan sarapan dan merasa lapar maka mereka akan mengkonsumsi makanan berkalori lebih tinggi yang didapatkan dari makanan jajanan. Penelitian di Amerika Serikat menunjukkan bahwa anak-anak dan remaja yang terbiasa melewatkan sarapan akan memiliki risiko 3 kali lebih tinggi untuk ngemil dan sulit mengontrol nafsu makan mereka sehingga dapat menyebabkan obesitas. ${ }^{11}$ Penelitian yang dilakukan oleh Weni Kurdanti pada tahun 2015, faktor yang secara bermakna berhubungan $(\mathrm{p}<0,05)$ dan menjadi faktor risiko terjadinya obesitas pada remaja adalah asupan energi (OR=4,69; CI:2,12-10,35) $(p=0,000)$; lemak $(\mathrm{OR}=2,34$; CI:1,19-4,57) $(p=$ $0,012)$; karbohidrat $(\mathrm{OR}=2,64 ; \mathrm{CI}: 1,34-5,20)(p=0,004)$; frekuensi fast food $(\mathrm{OR}=2,47$; CI: 1,26- 4,83) $(p=0,008)$; dan asupan sarapan pagi $(\mathrm{OR}=5,24 ; \mathrm{CI}: 2,56-10,71)(p=0,000){ }^{8}$

Aktivitas fisik adalah berbagai jenis gerakan yang dilakukan sehari -hari yang melibatkan otototot skeletal dan pengeluaran energi dan merupakan suatu bentuk perilaku rutinitas yang menggerakkan tubuh. Aktiftas fisik meliputi semua gerakantubuhdari gerakan kecil hingga gerakan berat dan cepat seperti lari maraton. ${ }^{12}$ Penelitian yang dilakukan oleh Bangun Ikhtiar Ibrahim pada tahun 2018, hasil penelitian sebagian besar responden melakukan aktivitas fisik sedang 13 (50,0\%), kejadian obesitas 26 $(10,1 \%)$. Ada hubungan aktivitas fisik dengan kejadian obesitas pada remaja di SMAN 1 Gamping Sleman Yogyakarta dengan nilai signifikan $0,011(\mathrm{p}<0,05)$ dan keeratan hubungan signifikan $\mathrm{r}(-0,49)$ menunjukkan hubungan negatif sedang. ${ }^{13}$

Berdasarkan studi pendahuluan yang telah peneliti lakukan di sekolah SMA 13 Bekasi melalui wawancara dan pengukuran BB dan TB kepada 10 responden, diketahui bahwa dari 10 responden didapatkan hasil bahwa 6 diantaranya mengalami obesitas dan 4 responden tidak obesitas, dari 10 responden didapatkan bahwa ada 8 responden memiliki kebiasaan mengkonsumsi fast food dan 2 responden lainnya tidak memiliki kebiasaan mengkonsumsi fast food, dari 10 responden didapatkan bahwa ada 7 diantaranya yang jarang sarapan pagi dan 3 responden lainnya rutin sarapan pagi, dan dari 10 responden didapatkan bahwa ada 5 responden yang memiliki aktivitas fisik tidak baik dan 5 responden memiliki aktivitas fisik baik.

Berdasarkan latar belakang di atas, penulis tertarik untuk melakukan penelitian tentang pengaruh konsumsi fast food, asupan sarapan pagi dan aktivitas fisik terhadap kejadian obesitas pada remaja putri di sekolah SMA 13 Bekasi tahun 2019. Tujuan dari penelitian ini adalah untuk mengetahui pengaruh konsumsi fast food, asupan sarapan pagi dan aktivitas fisik terhadap kejadian obesitas pada remaja putri di sekolah SMA 13 Bekasi tahun 2019.

\section{Metode}

Jenis penelitian ini menggunakan metode penelitian deskriptif kuantitatif dengan desain penelitian Cross Sectional yaitu penelitian dimana pengambilan data pada variabel sebab atau resiko dan akibat atau kasus yang terjadi pada suatu objek penelitian di ukur atau dikumpulkan secara bersamaan atau sekaligus. ${ }^{14}$ Penelitian kuantitatif adalah sebuah metode penelitian yang memberlakukan kuantifikasi pada variabel-variabelnya, menguraikan distribusi variabel secara numerik. Untuk mengetahui pengaruh konsumsi fast food, asupan sarapan pagi dan aktivitas fisik terhadap kejadian obesitas pada remaja putri di sekolah SMA 13 Bekasi tahun 2019.

Penelitian ini dilaksanakan pada bulan Desember 2019. Populasi yaitu keseluruhan objek penelitian yang akan diteliti. ${ }^{15}$ Populasi dalam penelitian ini yaitu seluruh remaja putri di SMA 13 Bekasi yaitu sebanyak 70 responden. Sampel merupakan objek yangakan diteliti dan dianggap mewakili dari populasi. Pada penelitian ini menggunakan alat analisis Structural Equation Modeling (SEM) dengan 


\section{SIMFISIS Jurnal Kebidanan Indonesia}

Volume 01, Nomor 01, Agustus 2021

Partial Least Square (PLS) berdasarkan pada maka penentuan jumlah sampel yang reseventatif ialah dengan cara jumlah indikator dikali dengan $5-10 .{ }^{16}$ Total indikator dalam penelitian ini ialah 7 ukuran sampelnya berada pada rentang 35 sampai 70 . Berdasarkan keterangan tersebut maka ukuran sampel dalam penelitian ini digunakan sebanyak 70 responden atau sampel.

Metode pengambilan sampel ialah dengan metode accidental sampling, karena pengambilan anggota sampel berdasarkan kebetulan, yaitu siapa saja yang secara kebetulan atau insidental bertemu dengan peneliti dapat digunakan sebagai sampel, bila dipandang orang yang kebetulan ditemui itu cocok sebagai sumber data. ${ }^{17}$ Pengolahan uji coba instrumen menggunakan komputerisasi. Pengumpulan data dilakukan setelah peneliti mendapatkan surat izin dari institusi yang akan ditunjukkan kepada tempat penelitian yaitu di SMA 13 Bekasi. Sebelum dilakukan penelitian, responden yang menjadi subjek penelitian diberikan kepada subjek penelitian dan hasil pengisian kuesioner sifatnya dirahasiakan setiap responden diberikan juga hak untuk menyetujui apakah bersedia menjadi responden atau menolak menjadi subjek penelitian. Dan responden yang menyetujui akan diberikan lembar persetujuan yang telah disiapkan oleh peneliti.

Metode pengukuran yang dipakai dalam penelitian ini menggunakan skala interval, sedangkan teknik pengukurannya menggunakan Semantic Differential yang mempunyai skala 5 poin pada setiap pernyataan atau pertanyaan. Pengolahan data pada penelitian ini dilakukan secara komputerisasi dengan mengolah data-data yang diperoleh dari hasil kuesioner yang diisi responden. Dalam penelitian ini analisis data menggunakan pendekatan Partial Least Square (PLS) dengan menggunakan software SmartPLS PLS merupakan jenis Structural Equation Model's yang berbasis komponen dengan sifat konstruk formatif.

PLS dapat disebut sebagai teknik predicton-oriented. Pendekatan PLS secara khusus berguna juga untuk memprediksi variabel independen. Pendekatan PLS adalah distribution free (tidak mengasumsikan data berdistribusi tertentu, dapat berupa nominal, ordinal, interval, dan rasio). Metode PLS mempunyai keunggulan tersendiri diantaranya datanya tidak harus berdistribusi normal multivariate (indikator dengan skala kategori, ordinal, interval sampai rasio dapat digunakan pada model yang sama) dan ukuran sampel tidak harus besar rasio dapat digunakan pada model yang sama) dan ukuran sampel tidak harus besar rasio dapat digunakan pada model yang sama) dan ukuran sampel tidak harus besar. Walaupun PLS digunakan untuk menjelaskan ada atau tidaknya hubungan antara variabel laten.

\section{Hasil}

Gambaran deskriptif sebaran jawaban responden terhadap pernyataan dalam angket terdapat pada tabel 1 .

Tabel 1. Rentang Kisaran Jawaban Responden di SMA 13 Bekasi tahun 2019

\begin{tabular}{lccccc}
\hline Variabel penelitian & $\begin{array}{c}\text { Rentang } \\
\text { kuesioner }\end{array}$ & $\begin{array}{c}\text { Rata-rata } \\
\text { Kuesioner }\end{array}$ & $\begin{array}{c}\text { Rentang } \\
\text { Aktual }\end{array}$ & $\begin{array}{c}\text { Rata-rata } \\
\text { Aktual }\end{array}$ & $\begin{array}{c}\text { Standar } \\
\text { Deviasi }\end{array}$ \\
\hline Konsumsi Fastfood & $10-50$ & 30 & $16-39$ & 28,34 & 6,620 \\
\hline Asupan Sarapan Pagi & $10-50$ & 30 & $16-39$ & 28,31 & 6,626 \\
\hline Aktivitas Fisik & $14-70$ & 42 & $25-58$ & 40,43 & 8,598 \\
\hline
\end{tabular}

Sumber: Hasil olah data penelitian tahun 2019 


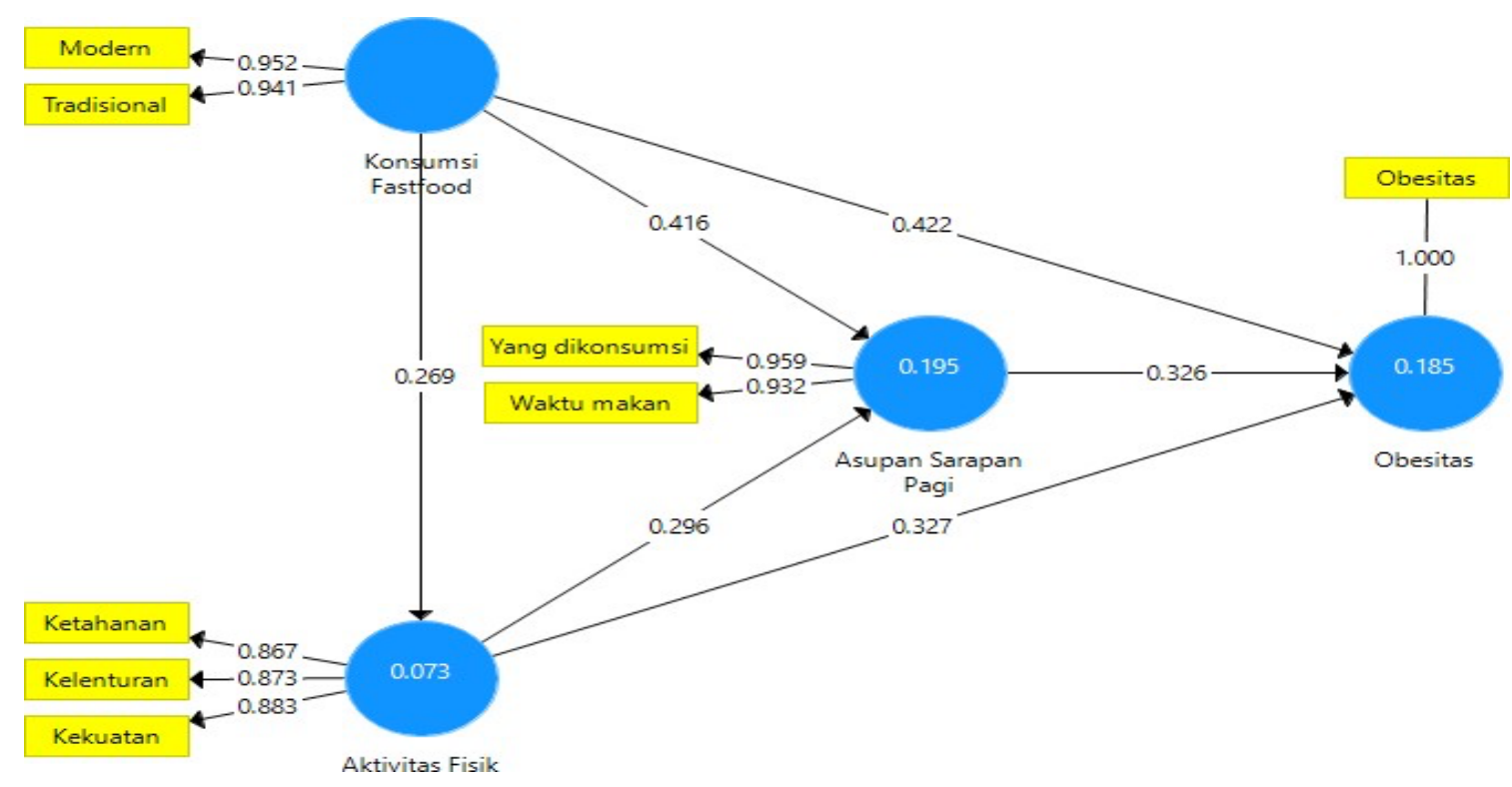

Gambar 1. Output PLS (loading factor)

Pada evaluasi outer model dengan indikator refleksif dievaluasi dengan convergent dan discriminant validity dari indikatornya, composite reliability untuk blok indikator, dan AVE serta nilai composite reliability. Sedangkan outer model dengan formatif indikator dievaluasi berdasarkan substantive content-nya ialah dengan membandingkan besarnya relative weight dan melihat signifikan dari ukuran weight tersebut. Suatu indikator dinyatakan valid jika mempunyai loading faktor tertinggi kepada variabel yang dituju dibandingkan loading faktor kepada variabel lain.

Nilai loading factor untuk fastfood modern dan fastfood tradisional tertinggi untuk variabel lainnya, sehingga variabel konsumsi fastfood mampu memprediksi nilai factor loading fastfood modern dan fastfood tradisional lebih tinggi dari variabel lainnya. Sedangkan nilai loading factor untuk ketahanan, kelenturan dan kekuatan tertinggi untuk variabel lainnya, sehingga variabel aktivitas fisik mampu memprediksi nilai factor loading ketahanan, kelenturan dan kekuatan lebih tinggi dari variabel lainnya. Sedangkan nilai loading factor untuk makanan yang dikonsumsi dan waktu makan tertinggi untuk variabel lainnya, sehingga variabel asupan sarapan pagi mampu memprediksi nilai factor loading makanan yang dikonsumsi dan waktu makan lebih tinggi dari variabel lainnya.

Berdasarkan gambar 1 dinyatakan bahwa nilai faktor loading telah memenuhi persyaratan yaitu nilai loading factors lebih besar dari 0,5 . Suatu indikator reflektif dinyatakan valid jika mempunyai loading factor diatas 0,5 terhadap variabel yang dituju berdasarkan pada substantive content-nya dengan melihat nilai signifikan dari weight $(\mathrm{t}=1,96)$. Hasil analisis pengolahan data dapat terlihat bahwa konstruk yang digunakan untuk membentuk model penelitian dalam proses analisis faktor konfirmasi telah memenuhi kriteria ini menunjukkan nilai diatas batas signifikan yaitu 0,05 . 


\section{Tabel 2. Hasil AVE}

\begin{tabular}{lccc}
\hline \multirow{2}{*}{ Pengaruh } & \multicolumn{2}{c}{ Hasil Uji } & Kriteria \\
\cline { 2 - 3 } & A & Akar $\boldsymbol{A V} \boldsymbol{E}$ & $\mathbf{0 , 5}$ \\
\hline Aktivitas Fisik & 0,764378 & 0,874287 & Valid \\
\hline Asupan (Sarapan Pagi) & 0,894058 & 0,945546 & Valid \\
\hline Konsumsi Fast Food & 0,896687 & 0,946936 & Valid \\
\hline Obesitas & 1,000000 & 1,000000 & Valid \\
\hline Sumber: SmartPLS 3, 0, report 2019 & & &
\end{tabular}

Cara lain untuk menguji discriminant validity dengan melihat nilai square root of average variance extracted (AVE). Nilai yang diharapkan diatas 0,50. Berdasarkan tabel 2 dapat dilihat bahwa semua variabel dinyatakan valid karena memberikan nilai AVE diatas 0,50 . Sehingga dapat disimpulkan bahwa evaluasi pengukuran model memiliki discriminant validity yang baik. Metode lain menunjukkan nilai akar kuadrat AVE lebih besar dari nilai square root of average variance extracted (AVE) setiap variabel, sehingga dapat disimpulkan bahwa evaluasi pengukuran model memiliki discriminant validity yang baik. Setelah diuji validitas dan dinyatakan variabel dan indikator telah valid, maka dilakukan uji reliabilitas. Hasil reliabilitas outer model dengan mengevaluasi nilai Cronbach's Alpha dan Composite Reliability. Jika hasil analisis pengolahan data, baik Cronbach's Alpha dan Composite Reliability dari setiap konstruk memiliki nilai lebih besar dari 0,70 maka semua konstruk dalam model yang diestimasi memenuhi syarat construct reliability. Setelah dilakukan bootstrapping untuk mengukur nilai T-statistik dari masing-masing konstruk laten terhadap konstruknya, maka nilai t-statistik dibandingkan dengan nilai $\alpha=0,05(1,96)$.

Berdasarkan gambar 2. dapat dilihat bahwa hasil pengukuran nilai t-statistik dari setiap indikator ke variabel lebih besar dari 1,96 dengan tingkat kepercayaan 95\% $(\alpha=0,05)$. Hal itu berarti semua indikator berpengaruh secara signifikan terhadap variabel yang diteliti. Aktivitas fisik terhadap obesitas 2,670, aktivitas fisik terhadap asupan sarapan pagi 2,856, asupan sarapan pagi terhadap obesitas 3,042, konsumsi fastfood terhadap obesitas 4,062, konsumsi fastfood terhadap aktivitas fisik 2,344, konsumsi fastfood terhadap asupan sarapan pagi 4,391. Sehingga H0 ditolak karena nilai T- statistik tersebut jauh diatas nilai kristis $(1,96)$ sehingga signifikan pada $\alpha=5 \%$.

Konsumsi fastfood berpengaruh secara langsung dan tidak langsung terhadap obesitas pada remaja putri. Hasil uji koefisien parameter antara konsumsi fastfood terhadap obesitas menunjukkan terdapat pengaruh langsung sebesar 9,45\%, sedangkan untuk pengaruh tidak langsung mendapat nilai sebesar $0,31 \%$. Asupan sarapan pagi berpengaruh secara langsung dan tidak langsung terhadap obesitas pada remaja putri. Hasil uji koefisien parameter antara asupan sarapan pagi terhadap obesitas menunjukkan terdapat pengaruh langsung sebesar 4,04\%, sedangkan untuk pengaruh tidak langsung mendapat nilai sebesar $0,04 \%$. Aktivitas fisik berpengaruh secara langsung terhadap obesitas pada remaja putri. Hasil uji koefisien parameter antara aktivitas fisik terhadap obesitas menunjukkan terdapat pengaruh langsung sebesar $5,00 \%$. Sehingga nilai dari masing-masing pengaruh langsung variabel laten independen tersebut apabila secara bersama-sama menunjukkan kesesuaian dengan nilai $R$ Square atau dengan kata lain hal ini menyatakan bahwa variabel konsumsi fastfood, asupan sarapan pagi dan aktivitas fisik mampu menjelaskan variabel obesitas sebesar $(9,45 \%+4,04 \%+5,00 \%)=18,49 \%$. Sedangkan total pengaruh tidak langsung $(0,13 \%+0,04 \%)=0,17 \%$ serta total pengaruh langsung dan tidak langsung $(18,49 \%+0,17 \%)=18,67 \%$. 
Tabel 3. Presentase Pengaruh antar Variabel terhadap Variabel Kejadian Obesitas

\begin{tabular}{lccccccc}
\hline Sumber & $\begin{array}{c}\boldsymbol{L} \boldsymbol{V} \\
\text { Correlation }\end{array}$ & $\begin{array}{c}\text { Direct } \\
\text { path }\end{array}$ & $\begin{array}{c}\text { Inderect } \\
\text { path }\end{array}$ & Total & $\begin{array}{c}\text { Direct } \\
\text { \% }\end{array}$ & $\begin{array}{c}\text { Indirect } \\
\boldsymbol{\%}\end{array}$ & Total \% \\
\hline Aktivitas Fisik & 0,153 & 0,327 & - & 0,327 & 5,003 & - & 5,003 \\
Asupan Sarapan Pagi & 0,124 & 0,326 & 0,097 & 0,423 & 4,042 & 0,045 & 4,088 \\
Konsumsi Fastfood & $\begin{array}{c}0,224 \\
\text { Total }\end{array}$ & 0,422 & 0,250 & 0,672 & 9,453 & 0,131 & 9,584 \\
& & & & 18,498 & & 18,675 \\
\hline
\end{tabular}

Sumber: SmartPLS 3.0, report 2019



Gambar 2. Output PLS (T-statistik)

\section{Pembahasan}

\section{Pengaruh Konsumsi Fast food terhadap Obesitas}

Hasil uji terhadap koefisien parameter antara konsumsi fastfood terhadap obesitas pengaruh langsung sebesar 9,45\% dan pengaruh tidak langsung sebesar 0,13\%. Nilai T-Statistic sebesar 4,062084 dan signifikan pada $\alpha=5 \%$. Nilai $T$-Statistic tersebut berada diatas nilai kritis $(1,96)$. Berdasarkan hasil uji tersebut dapat dijelaskan bahwa pengaruh langsung konsumsi fastfood lebih besar nilainya dibandingkan dengan pengaruh tidak langsung dan signifikan ada pengaruh yang positif dari kedua variabel tersebut. Nilai T-statitik menunjukkan, bahwa ada pengaruh signifikan antara konsumsi fastfood terhadap obesitas pada remaja putri di sekolah SMA 13 Bekasi.

Hasil penelitian menunjukkan ada pengaruh signifikan antara konsumsi fastfood terhadap obesitas. Sehingga apabila sering mengkonsumsi fastfood dapat meningkatkan kejadian obesitas, begitupun sebaliknya apabila jarang atau bahkan tidak pernah mengkonsumsi fastfood dapat menurunkan angka kejadian obesitas. Dari kedua indikator ukur yang dimiliki variabel konsumsi fastfood, semua indikator mampu menjelaskan variabel konsumsi fastfood yaitu fastfood modern dan 


\section{SIMFISIS Jurnal Kebidanan Indonesia}

Volume 01, Nomor 01, Agustus 2021

fastfood tradisional. Fast food adalah makanann cepat saji yang dikonsumsi secara instant. Fast food memiliki ciri kandungan gizi tidak seimbang. Kebanyakan mengandung kalori tinggi, tetapi sangat rendah serat, fast food juga tinggi kandungan lemak (termasuk kolesterol), gula dan garam. Fast food dapat dibedakan menjadi dua macam, yaitu fast food yang berasal dari luar negeri yang lebih dikenal dengan sebutan fast food modern seperti McDonald's, Kentucky Fried Chicken, Texas Fried Chicken, Pizza Hut, A\&W, serta fast food tradisional seperti rumah makan padang, warung tegal, bakul sunda dan lainnya yang biasa menyediakan makanan seperti pecel lele, ayam bakar, bakso, somay dan lainnya. ${ }^{18}$

Secara umum makanan cepat saji terbagi menjadi beberapa jenis, yakni dari segi jenis kemasan, teknik olah dan sebagainya. Makanan cepat saji (fast food) dibedakan menjadi berbagai macam, diantaranya adalah makanan gorengan, makanan kalengan, makanan asinan, makanan daging yang di olah (hamburger, sosis, dan lain lain), makanan dan daging berlemak dan jerohan, olahan keju, mie instan, makanan yang dipanggang atau dibakar, sajian manis beku dan manisan kering. ${ }^{18}$ Hasil penelitian yang dilakukan oleh Sarbia A.Takumansang pada tahun 2017, hasil analisis uji Kendall T menunjukkan adanya hubungan konsumsi fast food terhadap obesitas remaja di SMP Muhammadiyah 9 Yogyakarta ditunjukkan dengan nilai 0,564 dengan $\mathrm{p}=0,01(\mathrm{p}<0,05){ }^{10}$

Menurut asumsi peneliti dapat disimpulkan fast food sering disebut sebagai makanan siap saji. Makanan siap saji yang dimaksud adalah jenis makanan yang dikemas, mudah disajikan, praktis, atau diolah dengan cara sederhana. Makanan tersebut umumya diproduksi oleh industri pengolahan pangan dengan teknologi tinggi dan memberikan berbagai zat aditif untuk mengawetkan dan memberikan cita rasa bagi produk tersebut. Fast food merupakan makanan siap saji yang mengandung tinggi kalori, tinggi lemak dan rendah serat. Kalori dan lemak yang berlebihan akan disimpan dalam tubuh, keadaaan demikian yang terus menerus akan mengakibatkan penimbunan sehingga membuat orang menjadi overweight.

\section{Pengaruh Aktivitas Fisik terhadap Obesitas}

Hasil uji terhadap koefisien parameter antara aktivitas fisik terhadap obesitas pengaruh langsung sebesar 5,00\%. Nilai T-Statistic sebesar 2,670548 dan signifikan pada $\alpha=5 \%$. Nilai T-Statistic tersebut berada diatas nilai kritis $(1,96)$. Nilai T-statitik menunjukkan, bahwa ada pengaruh signifikan antara aktivitas fisik terhadap obesitas pada remaja putri di sekolah SMA 13 Bekasi. Hasil penelitian menunjukkan, ada pengaruh signifikan antara aktivitas fisik terhadap obesitas. Apabila aktivitas fisik yang tidak baik dapat meningkatkan kejadian obesitas, begitupula sebaliknya apabila aktivitas fisik yang baik akan dapat menurukan kejadian obesitas. Dari ketiga indikator ukur yang dimiliki variabel aktivitas fisik, semua indikator mampu menjelaskan variabel aktivitas fisik yaitu ketahanan, kelenturan dan kekuatan.

Aktivitas fisik adalah gerakan yang dilakukan otot-otot tubuh dan system penunjang nya. Banyak nya energi yang dibutuhkan tergantung pada berapa banyak otot yang bergerak, berapa lama dan berapa berat pekerjaan yang dilakukan. Aktivitas fisik pada anak tergolong ringan disebabkan hanya kegiatan menonton televisi, sehingga tidak banyak energi yang terpakai, sementara itu konsumsi energy dari makanan tetap atau meningkat maka terjadilah ketidakseimbangan antara pemasukan dan kebutuhan energi. ${ }^{19}$ Ada 3 tipe aktivitas fisik yang dapat dilakukan untuk mempertahankan kesehatan tubuh, antara lain: Ketahanan (endurance): Aktifitas fisik yang bersifat untuk ketahanan dapat membantu jantung, paru-paru, otot dan sistem sirkulasi darah tetap sehat dan membuat kita lebih bertenaga. Untuk mendapatkan ketahanan maka aktivitas fisik yang dilakukan selama 30 menit (4-7 


\section{SIMFISIS Jurnal Kebidanan Indonesia}

Volume 01, Nomor 01, Agustus 2021

hari per minggu). Contoh kegiatannya seperti: berjalan kaki, lari ringan, berenang, senam, bermain tenis, berkebun dan kerja di taman. Keleturan (flexibility): Aktivitas fisik yang bersifat untuk kelenturan dapat membantu pergerakan lebih mudah, memepertahankan otot tubuh tetap lemas (lentur) dan sendi berfungsi dengan baik. Untuk mendapatkan kelenturan maka aktifitas fisik dilakukan selama 30 menit (4-7 hari/ minggu). Kegiatannya seperti : peregangan, senam taichi, yoga, mencuci pakain dan mengepel lantai tangan. Kekuatan (strength): Aktivitas fisik yang bersifat untuk kekuatan dapat membantu kerja otot tubuh dalam menahan sesuatu beban yang diterima, tulang tetap kuat dan mempertahankan bentuk tubuh serta membantu meningkatkan pencegahan terhadap penyakit seperti osteoporosis. Untuk mendapatkan kelenturan maka aktifitas fisik dilakukan selama 30 menit (2-4 hari/minggu). Kegiatannya seperti: push-up, naik turun tangga, angkat berat/beban, ikut kelas senam/fitness. ${ }^{20}$

Hasil penelitian yang dilakukan oleh Bangun Ikhtiar Ibrahim pada tahun 2018, hasil penelitian sebagian besar responden melakukan aktivitas fisik sedang 13 (50,0\%), kejadian obesitas $26(10,1 \%)$. Ada hubungan aktivitas fisik dengan kejadian obesitas pada remaja di SMAN 1 Gamping Sleman Yogyakarta dengan nilai signifikan $0,011(\mathrm{p}<0,05)$ dan keeratan hubungan signifikan $\mathrm{r}(-0,49)$ menunjukkan hubungan negatif sedang. ${ }^{13}$

Menurut asumsi peneliti Aktivitas fisik adalah berbagai jenis gerakan yang dilakukan sehari hari yang melibatkan otot -otot skeletal dan pengeluaran energi dan merupakan suatu bentuk perilaku rutinitas yang menggerakkan tubuh. Aktiftas fisik meliputi semua gerakan tubuh dari gerakan kecil hingga gerakan berat dan cepat seperti lari maraton. Aktivitas fisik merupakan perilaku positif sebagai pengontrol keseimbangan energi, setiap gerakan tubuh yang menyebabkan peningkatan, pengeluaran, atau pembakaran tenaga. Aktivitas fisik yang ringan pada masa remaja akan cenderung kurang aktif pada masa berikutnya. Hal tersebut merupakan salah satu faktor yang menyebabkan obesitas.

\section{Pengaruh Asupan Sarapan Pagi terhadap Obesitas}

Hasil uji terhadap koefisien parameter antara asupan sarapan pagi terhadap obesitas pengaruh langsung sebesar 4,04\%, dan pengaruh tidak langsung sebesar 0,04\%. Nilai T-Statistic sebesar 3,042960 dan signifikan pada $\alpha=5 \%$. Nilai T-Statistic tersebut berada diatas nilai kritis $(1,96)$. Berdasarkan hasil uji tersebut dapat dijelaskan bahwa pengaruh langsung asupan sarapan pagi lebih besar nilainya dibandingkan dengan pengaruh tidak langsung dan signifikan ada pengaruh yang positif dari kedua variabel tersebut. Nilai T- statitik menunjukkan, bahwa ada pengaruh signifikan antara asupan sarapan pagi terhadap obesitas pada remaja putri di sekolah SMA 13 Bekasi. Hasil penelitian menunjukkan, ada pengaruh signifikan antara asupan sarapan pagi terhadap obesitas. Apabila asupan sarapan pagi tidak baik maka akan meningkatkan kejadian obesitas, begitupula sebaliknya apabila asupan sarapan pagi baik maka akan menurunkan kejadian obesitas.

Sarapan pagi merupakan suatu kegiatan makan dan minum yang penting sebelum melakukan aktivitas fisik. Sarapan pagi adalah menu pertama makan seseorang. Biasanya sarapan pagi dilakukan mulai dari bangun pagi sampai pukul 09.00. Sarapan pagi yang baik memenuhi 15-30\% dari angka kebutuhan gizi harian dalam rangka mewujudkan hidup sehat, aktif dan cerdas. ${ }^{21}$ Sarapan pagi memiliki banyak manfaat bagi anak usia sekolah. Manfaat-manfaat tersebut antara lain menurunkan resiko obesitas, meningkatkan konsentrasi dan prestasi, mengurangi resiko anemia, status gizi yang normal, terhadap kemampuan fisik dan menurunkan resiko diabetes tipe $2 .{ }^{22}$

Hasil penelitian yang telah dilakukan oleh Weni Kurdanti pada tahun 2015, faktor yang secara bermakna berhubungan $(\mathrm{p}<0,05)$ dan menjadi faktor risiko terjadinya obesitas pada remaja adalah 


\section{SIMFISIS Jurnal Kebidanan Indonesia}

Volume 01, Nomor 01, Agustus 2021

asupan energi $(\mathrm{OR}=4,69$; $\mathrm{CI}: 2,12-10,35)(\mathrm{p}=0,000)$; lemak $(\mathrm{OR}=2,34$; CI:1,19-4,57) $(\mathrm{p}=0,012)$; karbohidrat $(\mathrm{OR}=2,64 ; \mathrm{CI}: 1,34-5,20)(\mathrm{p}=0,004)$; frekuensi fast food $(\mathrm{OR}=2,47$; CI: 1,26-4,83) $(\mathrm{p}=$ $0,008)$; dan asupan sarapan pagi $(\mathrm{OR}=5,24$; $\mathrm{CI}: 2,56-10,71)(\mathrm{p}=0,000){ }^{8}$

Menurut asumsi peneliti sarapan sebaiknya mengandung makanan sumber karbohidrat, protein, tinggi serat, dan rendah lemak. Melewatkan sarapan dapat berisiko untuk menjadi obesitas dan memiliki gangguan kesehatan. Obesitas dapat terjadi karena ketika anak tersebut melewatkan sarapan dan merasa lapar maka mereka akan mengkonsumsi makanan berkalori lebih tinggi yang didapatkan dari makanan jajanan. Penelitian di Amerika Serikat menunjukkan bahwa anak-anak dan remaja yang terbiasa melewatkan sarapan akan memiliki risiko 3 kali lebih tinggi untuk ngemil dan sulit mengontrol nafsu makan mereka sehingga dapat menyebabkan obesitas.

\section{Kesimpulan}

Berdasarkan hasil penelitian dan pembahasan dalam penelitian yang diperoleh, maka dapat disimpulkan bahwa terdapat pengaruh langsung konsumsi fast food terhadap kejadian obesitas pada remaja putri di sekolah SMA 13 Bekasi, sebesar 9,45\%, nilai T-Statistic sebesar 4,06 dan signifikan pada $\alpha=5 \%$. Terdapat pengaruh langsung aktivitas fisik terhadap obesitas pada remaja putri di sekolah SMA 13 Bekasi, sebesar 5,00\%, nilai T-Statistic sebesar 2,67 dan signifikan pada $\alpha=5 \%$. Terdapat pengaruh langsung asupan sarapan pagi terhadap kejadian obesitas pada remaja putri di sekolah SMA 13 Bekasi, sebesar 4,04\%, nilai T-Statistic sebesar 3,04 dan signifikan pada $\alpha=5 \%$.

Dengan adanya penelitian ini diharapkan para remaja dapat termotivasi untuk memiliki kesadaran untuk dapat meningkatkan pengetahun dan wawasannya mengenai kejadian obesitas pada remaja dan diharapkan agar remaja mengurangi mengkonsumsi makanan cepat saji atau fastfood agar kesehatan terjaga dan mencegah terjadinya obesitas, diharapkan agar dapat meningkatkan upaya promosi kesehatan dengan cara bekerjasama dengan puskesmas setempat untuk memberikan penyuluhan kesehatan kepada remaja terkait dengan kejadian obesitas pada remaja putri, diharapkan penelitian ini dapat menjadi data dasar untuk pengembangan penelitian lanjutan dengan menggunakan variabel penelitian yang berbeda untuk mengetahui faktor lain yang berpengaruh terhadap kejadian obesitas dan diharapkan hasil penelitian ini dapat memberikan manfaat bagi lembaga pendidikan, agar dapat memotivasi mahasiswa untuk melakukan penelitian yang lebih baik lagi.

\section{Konflik Kepentingan}

\section{Ucapan Terima Kasih}

\section{Pendanaan}

\section{References}

1. Sherwood L. Fisiologi Manusia Dari Sel Ke Sistem Edisi 8. Jakarta: EGC; 2014.

2. Adriani M WB. Peranan Gizi Dalam Siklus Kehidupan. Jakarta: Kencana Prenada Media Group; 2013.

3. Sargowo D A S. Pengaruh Komposisi Asupan Makan terhadap Komponen Sindrom Metabolik pada Remaja. Jurnal Kardiologi Indonesia. Vol. 32, No.1; 2011. 


\section{SIMFISIS Jurnal Kebidanan Indonesia}

Volume 01, Nomor 01, Agustus 2021

4. Suryaputra K N S R. Perbedaan Pola Makan dan Aktivitas Fisik antara Remaja Obesitas dengan Non Obesitas. Makara Kesehatan. Vol. 16, No. 1; 2012.

5. WHO. Obesity and Overweight. Retrieved September 09, 2019. 2016. http://www.who.int/Mediacentre/Factsheets/Fs311/En/.

6. Riskesdas 2018. Hasil Utama Riskesdas 2018. Jakarta: Kementerian Kesehatan Republik Indonesia; 2018.

7. Dinkes Provinsi Jawa Barat 2016. Profil Kesehatan. Bandung: Dinas Kesehatan; 2017.

8. Kurdanti W. Faktor-faktor yang Mempengaruhi Kejadian Obesitas pada Remaja. Jurnal Gizi Klinik Indonesia. Vol. 11, No. 4; 2015.

9. Susanti T. Hubungan Pola Konsumsi Fast Food Dengan Kejadian Obesitas Pada Remaja Di SMA Muhammadiyah 3 Yogyakarta. [Skripsi]. Yogyakarta: Universitas Alma Ata; 2016.

10. Takumansang S A. Hubungan Konsumsi Fast Food Terhadap Obesitas Remaja Di SMP Muhammadiyah 9 Yogyakarta. [Skripsi]. Yogyakarta: Universitas 'Aisyiyah; 2017.

11. Mariza Y Y. Hubungan antara Kebiasaan Sarapan dan Kebiasaan Jajan dengan Status Gizi Anak Sekolah Dasar di Kecamatan Pedurungan Kota Semarang. Journal of Nutrition College. Volume 2, No. 1; 2013.

12. Siswanto, Susila S. Metodologi Penelitian Kesehatan Dan Kedokteran. Edisi Pertama, Cetakan Kedua. Yogyakarta: Bursa Ilmu; 2014.

13. Ibrahim B I. Hubungan Aktivitas Fisik Dengan Kejadian Obesitas Pada Remaja Di SMAN 1 Gamping Sleman Yogyakarta. [Skripsi]. Yogyakarta: Universitas ‘Aisyiyah; 2018.

14. Notoatmodjo S. Metodologi Penelitian Kesehatan. Jakarta: Rineka Cipta; 2015.

15. Sugiyono. Metode Penelitian Kualitatif, Kuantitatif Dan R \& D. Bandung: Alfabeta; 2017.

16. Ghozali I. Aplikasi Analisis Multivariate Dengan Program SPSS. Semarang: BP Undip; 2016.

17. Sugiyono. Metode Penelitian Kuantitatif, Kualitatif Dan R\&D. Bandung: Alfabeta; 2016.

18. Widyastuti A. Pengetahuan, Sikap Dan Tindakan Mahasiswa Boga Universitas Negeri Yogyakarta Tentang Konsumsi Makanan Cepat Saji (Fast Food). [Skripsi]. Yogyakarta: UNY; 2017.

19. Yensasnidar. Faktor-Faktor yang Berhubungan dengan Kejadian Obesitas pada Murid Sekolah Dasar Negeri 11 Lubuk Buaya Kota Padang tahun 2018. Jurnal Kesehatan Perintis (Perintis's Health Journal), Vol. 5, No. 2; 2018.

20. Sriani. Hubungan Aktivitas Fisik dengan Kejadian Demensia di Posyandu Lansia Gesik Puskesmas Krembangan Selatan Surabaya. [Skripsi]. Surabaya: Universitas Muhammadiyah Surabaya; 2018.

21. Hardinsyah AM. Jenis Pangan Sarapan dan Perannya dalam Asupan Gizi Harian. Jenis Pangan Sarapan dan Perannya dalam Asupan Gizi Harian. 7 (2); 2012.

22. Purba D A. Faktor Determinan Kebiasaan Sarapan Pagi Siswa SDN 2 Way Gubag. [Skripsi]. Bandar Lampung: Unila; 2017. 